\section{Knowledge, attitude and practice} towards facemask use amid the COVID-19 pandemic among public transport drivers in Debre-Tabor

\section{town, Ethiopia}

\author{
Gashaw Mehiret Wubet ${ }^{1 *}$ and Libsuye Yalgaw Zimamu \\ 'School of Medicine, College of Medicine and Health Sciences, Debre-Tabor University, \\ Debre-Tabor, Ethiopia \\ ${ }^{2}$ Department of Nursing, College of Health Sciences, Debre-Tabor, Ethiopia
}

\section{Abstract}

Background: For the prevention of respiratory infection similar to the current pandemic COVID-19, face masks are considered an effective method. Coronavirus disease (COVID-19) is a highly transmittable virus that continues to disrupt livelihoods, particularly those of low-income segments of society, around the world has poor knowledge towards facemask at the same time has huge gape towards attitude which affects the behaviors. Therefore this study was aimed to assess knowledge, attitude, and practice towards facemask use amid the COVID-19 pandemic among public transport drivers in Debre-Tabor town, Ethiopia, 2021.

Methods: A cross-sectional study was conducted among 407 public transport drivers in Debre-Tabor town from July to August 2021. The study participants were selected using a simple random sampling technique after proportionally allocating the sample size from the total number of public transport drivers, and finally, study subjects were elected continuously working in DebreTabor Town public transport drivers. The data were collected by trained data collectors using a structured questionnaire with face-to-face interview administered questioners and an on-the-spot observational checklist. The collected data were checked, coded, and entered into SPSS version 23, and for data cleaning and analysis.

Result: A total of 407 drivers responded to the questionnaire with a response rate of $96.4 \%$ were participated in this study. The mean age was 32.75 years (range: $19-45$ years). Among them majority was male $383(94.1 \%)$ and the majority of $177(43.5 \%)$ were Bajaj drives. Among the responders, $114(28 \%)$ used radio to gather information, and $41(10.1 \%)$ drivers where were caught by COVID-19, but, only 30(7.4\%) were vaccinated COVID-19 vaccine. Knowledge, attitude and practices regarding facemask use among these drivers were $368(90.4 \%$ [95\% Cl: 87.7-93.1]). 163(40\% [95\% Cl: $37.5 \%-43.2 \%])$, and 23 ((5.6\%) [95\% Cl: $3.7 \%-8.3 \%]$ ) Regarding facemask use against COVID-19 infection respectively.

Conclusion and recommendation: The current study was able to demonstrate $90.4 \%$ of drivers had good knowledge. Positive attitude and practice levels of face mask use among drivers were less than half of them or $40 \%$, and $5.6 \%$ respectively. There is a high supply of Surgical Face masks but poor attitude and practice. Almost all of the participants don't wear a face mask despite having good knowledge about the transmission routes of COVID-19. The government COVID-19 prevention task force or health sector should be continued their awareness creation to bring behavioral change for the implementation of the COVID-19 prevention method, especially facemask.
More Information

*Address for Correspondence: Gashaw Mehiret Wubet, School of Medicine, College of Medicine and Health Sciences, Debre-Tabor University, Debre-Tabor, Ethiopia,

Email: mehiretg21stdr@gmail.com

Submitted: December 28, 2021

Approved: January 20, 2022

Published: January 21, 2022

How to cite this article: Wubet GM, Zimamu LY. Knowledge, attitude and practice towards facemask use amid the COVID-19 pandemic among public transport drivers in Debre-Tabor town, Ethiopia. J Community Med Health Solut. 2022; 3: 001-010.

DOI: 10.29328/journal.jcmhs. 1001013

Copyright License: () 2022 Wubet GM, et al. This is an open access article distributed under the Creative Commons Attribution License, which permits unrestricted use, distribution, and reproduction in any medium, provided the original work is properly cited.

Keywords: Attitude; Knowledge; Practices; Debra-Tabor; Ethiopia

Acronyms and Abbreviations: AOR: Adjusted Odds Ratio; COVID-19: Coronavirus Disease 2019; GDP: Gross Domestic Product; KM: Kilometer; MS Excel: Microsoft Excel; PPE: Personal Protective Equipment; SARS-CoV-2: Severe Acute Respiratory Syndrome Corona Virus 2; SPSS 23: Statistical Package Software for Social science) Version 23.0; UN: United Nations; WHO: World Health Organization

D) Check for updates

(f) OPEN ACCESS 


\section{Introduction}

Coronavirus disease 2019 (COVID-19) is a transmissible disease caused by severe acute respiratory syndrome coronavirus 2 (SARS-CoV-2). The first known case was identified in Wuhan, China in December 2019 [1]. The disease has since spread worldwide, leading to a continuing pandemic [1].

The world health organization (WHO) declared COVID-19 a pandemic [1]. According to the WHO, as of $25^{\text {th }}$ June 2021, a total of 180,844,266 cases of COVID-19 had been confirmed worldwide $(3,971,496$ confirmed in Africa). Information suggests that the two main routes of transmission of the COVID-19 virus are respiratory droplets and contact [3].

COVID-19 is an acute respiratory disease caused by SARS$\mathrm{CoV}-2$ that mainly affects the lungs and is associated with mental and neurological manifestations amongst others. Most COVID-19 patients experience fever, cough, fatigue, anorexia, and shortness of breath [4]. However, other nonspecific symptoms may include sore throat, nasal congestion, headache, diarrhea, nausea, and vomiting. Transmission of the SARS-CoV-2 virus can occur through direct, indirect, or close contact with secretions, such as saliva and respiratory secretions or respiratory droplets, expelled from an infected person [5].

It is known that the novel COVID-19 has an incubation period of 2 to 14 days during which all infected patients, asymptomatic with mild symptoms, transmission is easy to a non-infected person and this poses a challenge for early isolation and containment, of community transmission [6,7].

In Ethiopia, people infected with severe acute respiratory syndrome coronavirus 2 (SARS-CoV 2) have been increasing dramatically [8,9]. COVID-19 precaution measures such as wearing the mask is one of the main and easy-to-use prevention measures. However, it was not known previously to what extent drivers who have frequent daily contact with community members during the provision of transportation service were perceived to know about the efficacy of prevention measures [10].

According to the World Health Organization (WHO) June 26, 2021 report, about 181,191,564 confirmed cases and $3,925,324$ deaths have been reported globally [11]. And the Americas, Europe, and Southeast Asia were the most affected regions. In Africa, 5,399,250 confirmed cases and 140,574 deaths have been reported. However, South Africa, Morocco, Tunisia, Egypt, and Ethiopia (275,769 confirmed cases and 4,302 deaths) were among the countries highly burdened by the COVID-19 pandemic in Africa. COVID-19 is a highly communicable disease transmitted to susceptible individuals by respiratory droplets and nasopharyngeal secretion [12].

Several vaccines have been used worldwide to prevent
COVID-19 despite other prevention strategies [11]. However, the clinical setups and level of supportive measures employed varied across countries and it mainly depends on economic status [12].

The African economy and healthcare system were significantly affected by the COVID-19 pandemic $[12,13]$.

To reduce transmission of SARS-CoV-2, primary prevention strategies are feasible and the best option is wearing PPE in resource-limited settings. The use of facemasks is one of the indispensable measures to prevent the transmission of COVID-19 [14]. Maintaining physical distance, washing hands, staying home, and wearing face masks were the main measures recommended to prevent the disease worldwide [15].

Estimates show that COVID-19 would have resulted in 7 billion infections and 40 million deaths globally this year if no action had been taken Beyond causing morbidity and, the virus can have a great impact on the economy. A report by the United Nations (UN), has estimated that because of COVID-19 the African continent will face a 1.4 percentage point decline of gross domestic product (GDP) [16]. The use of face masks has been accepted and recommended globally as a tool for COVID-19 protection since the outbreak in China. Many countries are stockpiling face masks for use as a nonpharmaceutical intervention to control virus transmission during the pandemic. Depending on the type, masks can be used either for the protection of healthy persons or to prevent onward transmission (source control) [13,17].

Human-to-human transmission of SARS-CoV-2 occurs during exposure to infectious respiratory droplets or aerosols generated by humans with COVID-19. Aerosolizing events (AEs) contribute to the controversy regarding the selection of optimal personal protective equipment (PPE) for preventing transmission of SARS-CoV-2 to drivers' workers. Because of global PPE shortages, further studies examining the association of drivers' PPE uses with the acquisition of COVID-19 are needed to protect our drivers and decrease inappropriate PPE use $[14,15]$.

To minimize the risk, the public is required to follow accepted infection control practices [16] and these include community-based measures such as self-isolation, use of alcohol-based hand sanitizer or hand-washing with soap, restriction of movements with lockdown measures, sanitization of surfaces, and use of non-medical cloth mask or face covering or medical face mask which has greatly reduce aerosol and airborne disease especially COVID-19 [17-19]. A large variety of face masks have surfaced in the market during the current COVID-19 outbreak, largely due to the limited availability of proper face masks. There are different types of masks which are respirator masks, a respirator mask forms a tight seal around the nose and mouth and protects the user from being exposed to noxious particles, gases, and 
microorganisms including bacteria, viruses, and fungi. It was subsequently used during the SARS outbreak in 2003. Valve versus non-valve N95 respirators N95 respirator masks is available with a valve and without a valve. The valve N95 mask respirator is not suitable for patients suffering from COVID-19 as during exhalation they will allow the virus to pass out easily and can potentially infect people around them. The Surgical mask is also called the 'medical' mask which is currently more available than other types of mask and preferred by users or user-friendly. Cloth face masks show minimum efficacy in source control than medical-grade masks. The efficacy of cloth face masks filtration varies and depends on the type of material used, number of layers, and degree of moisture in the mask and fitting of the mask on the face which significantly reduce the incidence of the pandemic [20-22].

The world is struggling with an ever-changing COVID-19 pandemic using preventive measures such as personal hygiene, face masks, restrictions on travel, and gatherings in communities, in addition to a race to find a vaccine. Although drivers are particularly exposed to the virus, there a study was done to investigate the use of facemask among this population in Debra-Tabor town. Since there were no studies conducted on a risky population like drivers, the purpose of this study is to evaluate the knowledge, attitudes, and practices of the drivers on the proper use of face masks to mitigate the spread of COVID-19 in Debre-Tabor Town.

\section{Methods and materials}

\section{Study setting}

This study was conducted among drivers in the selected bus station and taxi/Bajaj waiting for the area and government sector of Debre-Tabor town, North Ethiopia. A cross-sectional study was conducted at Debre-Tabor Town which is the largest town of the south Gondar zone in the Amhara Regional State which is located at the central highlands of Ethiopia it is found $667 \mathrm{kms}$ away from Addis Ababa the capital city of Ethiopia in the northeastern direction.

Source population: All drivers who work in Debre-Tabor town were the source population.

\section{Study population}

All Drivers who were working at the bus, taxi/Bajaj stands of Debre-Tabor town during the data collection period were the study population.

\section{Inclusion and exclusions criteria}

Inclusion criteria: All drivers who drive Taxi, Bajaj, longrun bus, long-run minibus, and public service Bus work in Debre-Tabor town participate were included in the study.

Exclusions criteria: Those who work temporarily

\section{Study variables}

\section{Dependent variables}

Knowledge of drivers towards the use of a facemask

An attitude of drivers towards the use of facemasks

Practices of drivers towards the use of facemasks

Independent variables

Socio-demographic Characteristics

Mode of transmission

Contact routes, wearing a face mask, Source of information

Symptom for COVID-19

Facemask protect against COVID-19

Accept COVID-19 vaccine

Going to a public or crowded place

Share mask

Sample size and sampling technique

Sample Size Determination

A single population proportion formula

$n=\frac{(Z a / 2) 2 P(1-P)}{d 2}$ Used to estimate the sample size.

We used a previous study conducted in Addis Ababa, Ethiopia for maximum sample size assumptions (Proportion of $50 \%, 95 \%$ confidence level $(Z=1.96)$, and $5 \%$ margin of error. With this, the required sample size was 384 . By adding $10 \%$ nonresponse rates, a total of 422 drivers were planned to be involved in the study.

\section{Sampling technique}

Eight government sectors bus drivers, one Bus station, and 10 Bajaj/taxi waiting for stations "Fermata" (stands) were selected using the lottery method. Therefore, 177 taxies and Bajaj drivers and 30 Long run-bus and Minibus drivers are selected. Then, the daily average drivers who attended those stations and waiting areas units were estimated. Finally, based on their drivers' load, the sample was allocated proportionally. Finally, data were collected from eligible subjects by using a simple random sampling technique with convective sampling.

\section{Data collection tool and procedures}

An English version self-administered questionnaire was adapted from different kinds of literature used to collect data on all the specific objectives of the study and it translated into the Amharic language most study participants to be understood [5]. It contains different parts use to assess the following: socio-demographic characteristics, General knowledge of the participant, Attitude towards the use of facemasks among participants, Facemask use Practice on behavioral factors affecting face mask-wearing. The final 
and seventh section consists of questions to be filled by the interviewer by observation to be filled if the driver wears a facemask, Does he/she wear the facemask correctly. Finally, the questionnaire was administered to one supervisor (clinical pharmacy) and Two (Diploma Pharmacy Technician) Data collectors have participated.

\section{Data quality control}

The quality of data was ensured by doing the questionnaire pre-tested on $5 \%$ of the total sample size in Bahirdar town that is assumed to have similar characteristics to the targeted population. Based on their feedback the necessary amendment is done and the questionnaire is assessed for its clarity; the completeness and evaluate the validity and content of the questionnaire and modified accordingly. Close supervision is also made during the data collection and appropriate feedback is provided.

\section{Operational definitions}

Facemask wearing: Using a disposable or reusable device that creates a physical barrier between the mouth and nose of the wearer [23].

Good knowledge: Those study participants whose number of correct answers was above or equal to the mean score to nine knowledge questions about COVID-19 [8].

Poor knowledge: Those study participants whose number of correct answers was below the mean score to nine knowledge questions about COVID-19 [8].

Positive attitude: Those study participants whose number of correct answers was above or equal to the mean score to eleven attitude questions about taking precautions against the transmission of COVID-19 [24].

Negative attitude: Those study participants whose number of correct answers was below the mean score to eleven attitude questions about taking precautions against the transmission of COVID-19 [24].

The proportion of face mask-wearing: The number of drivers who were wearing a facemask that covered the nose, mouth, lower jaw, and facial hair at the time of data collection was divided by the total number of study participants [23].

\section{Data processing and analysis}

Primarily the data was checked for its completeness, consistency, and validity. After checking the collected data, then the data was entered into SPSS version 23 statistical software for analysis. Data were cleaned, and coded for completeness, consistency and to minimized errors. SPSS version 20 statistical software is used and frequencies and odds ratio was determined. After the data was analyzed the findings descriptive analyzed statistical results were presented by texts, graphs, diagrams, and tables.

\section{Results}

\section{Socio-demographic characteristics of study participants}

Four hundred seven (407) drivers, with a response rate of $96.4 \%$ were participated in this study. The mean and median age was 32.75 , and 30 years (range: 18-46 years) with the majority being in the age range of $26-35$ years $184(45.2 \%)$.

Among the respondents, males had a higher proportion $383(94.1 \%)$, and the majority of respondents $183(45.0 \%)$ educational status was Secondary/ high school education with only $28(6.9 \%)$ having Diploma and only $3(0.7 \%)$ Degree. Regarding marital status most of the study participants $230(56.5 \%)$ were single, while $131(32.2 \%)$ were married, $34(8.4 \%)$ were Divorced, and $12(2.9 \%)$ of them were widowed.

Higher numbers of drivers 177(43.5\%) drive Bajaj, Taxi 176(43.2\%), Public service bus 6 (1.5\%), Long-run bus $22(5.4 \%)$ and $34(8.2 \%)$ drives long-run minibus (Abadula, Airuf, Coaster), and Majority of drivers have driving experience of 5 years or less $313(76.9 \%)$. More than half of the participant's monthly income is between 1000-5000 Ethiopian birr (25-112\$) 265(65.1\%), and concerning their religion over half of the respondents, $244(60 \%)$ were orthodox Christian (Table 1).

Table 1: Socio-demographic characteristics of public transport drivers, Debre-Tabor, Ethiopia, 2021.

\begin{tabular}{|c|c|c|}
\hline Variables & Category & $n(\%)$ \\
\hline Gender & $\begin{array}{c}\text { Male } \\
\text { Female }\end{array}$ & $\begin{array}{c}383(94.1 \%) \\
24(5.9 \%)\end{array}$ \\
\hline Age & $\begin{array}{c}18-25 \\
26-35 \\
36-45 \\
46-55 \\
>55\end{array}$ & $\begin{array}{c}86(21.1 \%) \\
184(45.2 \%) \\
101(24.8 \%) \\
29(7.1 \%) \\
7(1.7 \%)\end{array}$ \\
\hline Religion & $\begin{array}{l}\text { Orthodox } \\
\text { Muslim } \\
\text { Catholic } \\
\text { Protestant } \\
\text { Jewish }\end{array}$ & $\begin{array}{c}244(60 \%) \\
123(30.2 \%) \\
3(0.7 \%) \\
36(8.8 \%) \\
1(0.2 \%)\end{array}$ \\
\hline Educational level & $\begin{array}{c}\text { No formal education } \\
\text { Elementary education } \\
\text { high school education } \\
\text { Preparatory education } \\
\text { Diploma } \\
\text { Degree }\end{array}$ & $\begin{array}{c}1(0.2 \%) \\
114(35.4 \%) \\
183(45.0 \%) \\
48(11.8 \%) \\
28(6.9 \%) \\
3(0.7 \%)\end{array}$ \\
\hline Marital status & $\begin{array}{c}\text { Single } \\
\text { Married } \\
\text { Widowed } \\
\text { Divorced }\end{array}$ & $\begin{array}{c}230(56.5 \%) \\
131(32.2 \%) \\
12(2.9 \%) \\
34(8.4 \%)\end{array}$ \\
\hline Type of car driven & $\begin{array}{c}\text { Taxi } \\
\text { Bajaj } \\
\text { Public service bus } \\
\text { Long run bus } \\
\text { long run minibus }\end{array}$ & $\begin{array}{c}176(43.2 \%) \\
177(43.5 \%) \\
6(1.5 \%) \\
22(5.4 \%) \\
34(8.2 \%)\end{array}$ \\
\hline Years of driving experience & $\begin{array}{c}<5 \\
5-10 \\
16-20 \\
>20\end{array}$ & $\begin{array}{c}313(76.9 \%) \\
77(18.9 \%) \\
15(3.7 \%) \\
2(0.5 \%)\end{array}$ \\
\hline Monthly income & $\begin{array}{c}<1000 \\
1000-5000 \\
5001-10000 \\
>10000\end{array}$ & $\begin{array}{c}7(1.7 \%) \\
265(65.1 \%) \\
126(31.0 \%) \\
9(2.2 \%)\end{array}$ \\
\hline
\end{tabular}




\section{Knowledge of the study participants}

Out of the total study subjects, 55(13.5\%) of respondents testified to have a chronic disease, from these 21(38.2\%), $23(41.8 \%)$, and $11(20 \%)$ have DM, HTN, and Asthma respectively the relationship between the facemask and chronic disease were not addressed even though those who have the chronic disease have a high risk of severing COVID disease. One hundred forty-five $(35.6 \%)$ of drivers are employed, only 94(23.1\%) drive their vehicle. Among the employed participants only $12 \%$ of the employers provide protective measures.

On the line of COVID-19 infection, 49(12\%) of the respondents from the total were caught due to their poor self-care \& lack of proper prevention methods like social distancing, hand washing, and facemask.

Regarding the source of information majority of drivers or respondents get any COVID-19 related information $114(28.0 \%)$ were from Radio, 56(13.8\%) from TV, informal discussions among their friends $68(16.7 \%)$ as a source of information regarding COVID-19 pandemic, among social media, Radio is the major information provider $114(28.0 \%)$ then Telegram 18(4.4\%) and Youtube 13(3.2\%). Additionally more than half of respondents $253(62.2 \%)$ refuse to isolate themselves if they develop a sign and symptom of COVID-19. From the participants, $30(7.4 \%)$ claimed to be vaccinated against COVID-19 among those only 2(0.5\%) of them took both the first and second dose of the vaccine, the remaining $44(10.8 \%)$ do not want to be vaccinated while $18(4.4 \%)$ do have the information about the vaccine how and where to get vaccinated.

Assessment of knowledge was made using nine sets of questions regarding mechanisms of COVID-19 transmissions and basic strategies outlined by WHO guidelines as means of infection prevention and control. The respondents of this study had overall good knowledge regarding facemask use against COVID-19 infection which was $(n=368,90.4 \%$ [95\% CI: 87.7-93.1]). Two hundred seventy-five (67.6\%) of drivers considered COVID-19 as a fatal disease and 121(29.7\%) of respondents knew the signs and symptoms of COVID-19 which is (Fever, fatigue, dry cough, myalgia), while 254(62.4\%) of them uncertain whether this are the manifestation of the viral disease.

The majority of study subjects 278(68.\%) knew the transmission routes of COVID-19 (Through the air, physical contact). moreover, $178(43.7 \%)$ of the participants were aware of which side of a face mask should be inwards and which should face outwards. But, on the other hand below half of respondent's $105(25.8 \%)$ agreed that wearing a facemask protects against the pandemic while $260(63.9 \%)$ believe that wearing Facemask will not protect from COVID-19, the remaining 91(22.3\%) are not certain if Facemasks protect from COVID-19. 260(63.8\%) of participants disagree with wearing a face mask in the absence of COVID-19. Among the participants, most of them 221(54.3\%) don't know the purpose of the metal strip on a surgical mask, seventeen percent $(17.2 \%)$ of the study subjects are uncertain about the function of the metal strip found on a surgical mask. Only $110(27 \%)$ claimed to know the characteristics/ differences between the different types of face masks (Surgical mask, N95, Cloth mask) while 229(56.3\%) does not aware of the difference the remaining 68(16.7\%) are unsure about the differences among the different type of masks (Table 2).

\section{The attitude of the respondents}

Overall proportion of positive attitude is $40.3 \%$ [95\% CI: 35.6-58.9]. Among Public Transport drivers currently working in Debre-Tabor town, Ethiopia 104(25.6\%) participants believe that a Cloth face mask is as effective as a regular surgical face mask or N95 in limiting the spread of COVID-19 protective against COVID-19. However, 140(34.4\%) of them are disagreeing on cloth face masks other than surgical, and N95 face masks.

Moreover, the majority of responders 253(62.2\%) believed that It's difficult for others to see their facial expressions when wearing a face mask, and 289(71.0\%) respondents responded that they experience breathing difficulty when wearing a face mask, 253(62.2\%) study subjects reported that Face mask irritates their face.

More than half of drivers 195(47.9\%) agree that people misinterprets their feeling when wearing a face mask while $115(28.3 \%)$ were neutral. Fifty-four (13.3\%) feel embarrassed when wearing a face mask while $279(68.6 \%)$ disagree with feeling embarrassed. A higher proportion of participants $180(44.2 \%)$ didn't consider the appearance of face masks as unpleasant, 233(57.2\%) feels uncomfortable when wearing a face mask, most of the $289(71.0 \%)$ reported having breathing difficulty when wearing a face mask. More than half of the respondents 268(66.1\%) believe Facemask makes them unattractive. 164(40.2\%) feel they don't need to wear a face mask; other people should take care of themselves while most others 200(49.1\%) disagree with this (Table 3).

\section{The practice of drivers about wearing a mask to prevent transmission of COVID-19}

In general, drivers practicing in the aim of COVID-19 pandemic only $23(5.6 \%)$ always wear a face mask when working or driving properly utilizes their face mask. It is interesting to note that majority of respondents $166(40.8 \%)$ reported wearing their face masks by the order of a Security officer (traffic police). Most of the participants 307(75.4\%) didn't always wash their hands before wearing a face mask while $116(28.5 \%)$ of respondents never washed their hands after removing a face mask, and, moreover, a little more than half of the drivers wash 175 their hands with soap and water/ use a sanitizer after touching the face mask, regarding the 
Knowledge, attitude and practice towards facemask use amid the COVID-19 pandemic among public transport drivers in Debre-Tabor town, Ethiopia

Table 2: General information about public transport Drivers, Debre-Tabor, Northern Ethiopia 2021

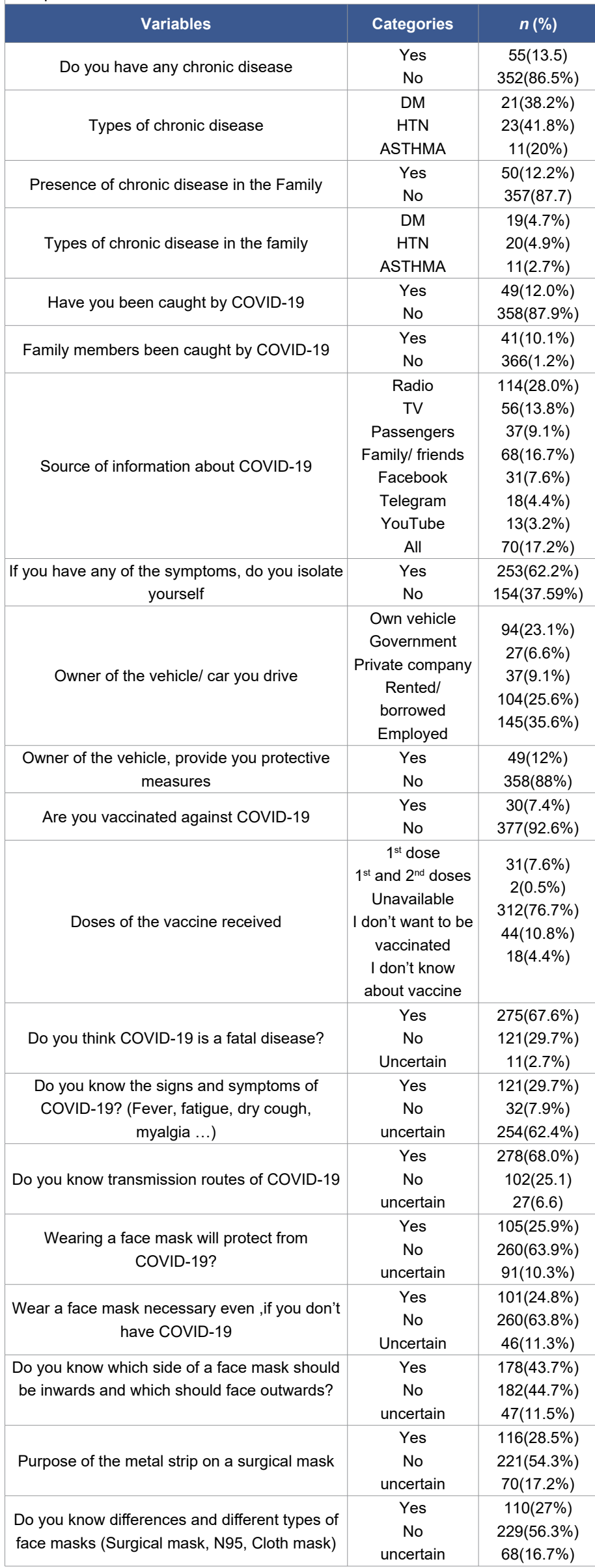

Table 3: Attitudes of Public transport Drivers, Debre-Tabor Northern Ethiopia, 2021.

\begin{tabular}{|c|c|c|}
\hline Variables & Categories & $n(\%)$ \\
\hline $\begin{array}{l}\text { Cloth facemask is as effective as a regular } \\
\text { surgical facemask or N95 in limiting the } \\
\text { spread of COVID-19 }\end{array}$ & $\begin{array}{l}\text { Agree } \\
\text { Neutral } \\
\text { disagree }\end{array}$ & $\begin{array}{c}104(25.6 \%) \\
163(40 \%) \\
140(34.4 \%)\end{array}$ \\
\hline $\begin{array}{l}\text { It's difficult for others to see my facial } \\
\text { expressions when wearing a facemask }\end{array}$ & $\begin{array}{l}\text { Agree } \\
\text { Neutral } \\
\text { disagree }\end{array}$ & $\begin{array}{l}253(62.2 \%) \\
77(18.9 \%) \\
77(18.9 \%)\end{array}$ \\
\hline $\begin{array}{l}\text { People will misinterpret my feelings when } \\
\text { wearing a facemask }\end{array}$ & $\begin{array}{l}\text { Agree } \\
\text { Neutral } \\
\text { disagree }\end{array}$ & $\begin{array}{l}195(47.9 \%) \\
115(28.3 \%) \\
97(23.8 \%)\end{array}$ \\
\hline $\begin{array}{l}\text { I feel embarrassed when wearing a } \\
\text { facemask }\end{array}$ & $\begin{array}{c}\text { Agree } \\
\text { Neutral } \\
\text { Disagree }\end{array}$ & $\begin{array}{l}54(13.3 \%) \\
74(18.2 \%) \\
279(68.6 \%)\end{array}$ \\
\hline Wearing facemask makes me unattractive & $\begin{array}{c}\text { Agree } \\
\text { Neutral } \\
\text { Disagree }\end{array}$ & $\begin{array}{l}64(15.7 \%) \\
74(18.2 \%) \\
269(66.1 \%)\end{array}$ \\
\hline The appearance of facemask is unpleasant & $\begin{array}{c}\text { Agree } \\
\text { Neutral } \\
\text { Disagree }\end{array}$ & $\begin{array}{c}147(36.1 \%) \\
80(19.7 \%) \\
180(44.2 \%)\end{array}$ \\
\hline $\begin{array}{l}\text { I have a breathing difficulty when wearing } \\
\qquad \text { a facemask }\end{array}$ & $\begin{array}{c}\text { Agree } \\
\text { Neutral } \\
\text { Disagree }\end{array}$ & $\begin{array}{c}289(71.0 \%) \\
34(8.4 \%) \\
84(20.6 \%)\end{array}$ \\
\hline Facemask irritates my face & $\begin{array}{c}\text { Agree } \\
\text { Neutral } \\
\text { Disagree }\end{array}$ & $\begin{array}{c}253(62.2 \%) \\
39(9.6 \%) \\
115(28.3 \%)\end{array}$ \\
\hline Facemask causes ear pain & $\begin{array}{c}\text { Agree } \\
\text { Neutral } \\
\text { Disagree }\end{array}$ & $\begin{array}{c}253(62.2 \%) \\
24(5.9 \%) \\
130(31.9 \%)\end{array}$ \\
\hline $\begin{array}{l}\text { I don't need to wear a facemask; other } \\
\text { people should take care of themselves }\end{array}$ & $\begin{array}{c}\text { Agree } \\
\text { Neutral } \\
\text { Disagree }\end{array}$ & $\begin{array}{c}164(40.2 \%) \\
43(10.6 \%) \\
200(49.1 \%)\end{array}$ \\
\hline $\begin{array}{l}\text { I feel embarrassed when wearing a } \\
\text { facemask }\end{array}$ & $\begin{array}{c}\text { Agree } \\
\text { Neutral } \\
\text { Disagree }\end{array}$ & $\begin{array}{c}54(13.3 \%) \\
74(18.2 \%) \\
279(68.6 \%)\end{array}$ \\
\hline $\begin{array}{l}\text { People will misinterpret my feeling when I } \\
\text { wearing a facemask }\end{array}$ & $\begin{array}{c}\text { Agree } \\
\text { Neutral } \\
\text { Disagree }\end{array}$ & $\begin{array}{c}97(23.8 \%) \\
115(28.3 \%) \\
195(47.9 \%)\end{array}$ \\
\hline $\begin{array}{l}\text { I have breathing difficulty when I wear } \\
\text { facemask }\end{array}$ & $\begin{array}{c}\text { Agree } \\
\text { Neutral } \\
\text { Disagree }\end{array}$ & $\begin{array}{c}289(71 \%) \\
34(8.4 \%) \\
84(20.6 \%)\end{array}$ \\
\hline Wearing facemask makes me unattractive & $\begin{array}{c}\text { Agree } \\
\text { Neutral } \\
\text { Disagree }\end{array}$ & $\begin{array}{c}268(66.1 \%) \\
74(18.2 \%) \\
64(15.7 \%)\end{array}$ \\
\hline
\end{tabular}

removal practice of the respondents, the report shows a good one since more than half of drivers $289(71 \%)$ hold both ear loops and lift and remove the face mask nevertheless $33(8.1 \%)$ drivers admitted sharing a face mask with other people while a good proportion of the respondents 374(91.9\%) never shared their facemask. The type of face mask usually used is reported chronologically in order as Surgical/medical facemask 254(62.4\%), then Cloth facemasks 145(35.6\%) and N95 facemask $8(2.0 \%)$. When wearing a facemask more than half of the respondents $351(86.2 \%)$ admitted keeping the used facemask in their pocket for later use. Connected to this $146(35.9 \%)$ of the participants reported using a single-use facemask three times while a greater number $172(42.2 \%)$ of study subjects uses for more than 3 times. Regarding disposal of the masks, 192(47.2\%) use open disposal, 25(6.1\%) of the participants burn, only $135(33.2 \%)$ of them put the masks in a pit or bin. The other 33(8.1\%) throw in the toilet the remaining $22(5.4 \%)$ reported that they put facemasks in the aplastic bag for later use. Findings From our observation shows that 387(95.0\%) of drivers do not wear a facemask, and out of those only $43(10.6 \%)$ wore the facemask correctly 
(not reverted, covered the nose, mouth, and chin fully. The observation of interviewers from study participants in the assessment of knowledge, attitude and practice of public transport drivers regarding facemask utilization are wearing habit which collected by observational checklist was only twenty $4.9 \%$ drivers were wearing facemask during the observation, and from those respondents or study subjects the only $17(4.2 \%)$ were worn correctly that is covering the nose, mouth, chin fully and not inverted (Table 4).

\section{Behavioral factors affecting face mask-wearing}

The majority of respondents $303(74.4 \%)$ believed that COVID-19 is a punishment from GOD, 253(62.2\%) of them

Table 4: Practice of Public transport Drivers, Debre-Tabor, Northern Ethiopia, 2021.

\begin{tabular}{|c|c|c|}
\hline Variables & Categories & $n(\%)$ \\
\hline $\begin{array}{c}\text { Do you always wear face mask when } \\
\text { working/ driving? }\end{array}$ & $\begin{array}{l}\text { Yes } \\
\text { No }\end{array}$ & $\begin{array}{c}23(4.9 \%) \\
384(94.3 \%)\end{array}$ \\
\hline $\begin{array}{l}\text { If your answer for the above question } \\
\text { was "No", how often do you were a face } \\
\text { mask? }\end{array}$ & $\begin{array}{c}\text { By passengers } \\
\text { Myself } \\
\text { Security officer (traffic } \\
\text { police) } \\
\text { Only when coughing } \\
\text { Passenger in the car } \\
\text { All }\end{array}$ & $\begin{array}{c}16(3.9 \%) \\
72(17.7 \%) \\
166(40.8 \%) \\
77(18.9 \%) \\
38(9.3 \%) \\
38(9.3 \%)\end{array}$ \\
\hline $\begin{array}{l}\text { What type of face mask do you usually } \\
\text { use/ wear? }\end{array}$ & $\begin{array}{l}\text { Surgical/medical facemask } \\
\text { N95 facemask } \\
\text { Cloth facemasks }\end{array}$ & $\begin{array}{l}254(62.4 \%) \\
8(2.0 \%) \\
145(35.6 \%)\end{array}$ \\
\hline $\begin{array}{c}\text { Do you always wash your hands before } \\
\text { wearing a face mask? }\end{array}$ & $\begin{array}{l}\text { Yes } \\
\text { No }\end{array}$ & $\begin{array}{l}100(24.6 \%) \\
307(75.4 \%)\end{array}$ \\
\hline $\begin{array}{c}\text { Do you always check the inside and } \\
\text { outside of the face mask before } \\
\text { wearing it? }\end{array}$ & $\begin{array}{l}\text { Yes } \\
\text { No }\end{array}$ & $\begin{array}{l}214(52.6 \%) \\
193(47.4 \%)\end{array}$ \\
\hline How do you wear a face mask? & $\begin{array}{l}\text { Cover the mouth only } \\
\text { Cover the nose only } \\
\text { Cover the chin } \\
\text { Cover the mouth, nose } \\
\text { and chin }\end{array}$ & $\begin{array}{l}47(11.5 \%) \\
25(6.1 \%) \\
14(3.4 \%) \\
321(78.9 \%)\end{array}$ \\
\hline $\begin{array}{l}\text { Do you frequently touch the face mask } \\
\text { with your hands after wearing it? }\end{array}$ & $\begin{array}{l}\text { Yes } \\
\text { No }\end{array}$ & $\begin{array}{l}244(55.0 \%) \\
183(44.9 \%)\end{array}$ \\
\hline $\begin{array}{l}\text { Do you wash your hands with soap and } \\
\text { water/ use a sanitizer after touching the } \\
\text { face mask? }\end{array}$ & $\begin{array}{l}\text { Yes } \\
\text { No }\end{array}$ & $\begin{array}{l}175(43.1 \%) \\
232(56.9 \%)\end{array}$ \\
\hline $\begin{array}{l}\text { How often do you wash your hands after } \\
\text { removing a face mask? }\end{array}$ & $\begin{array}{l}\text { Never } \\
\text { Sometimes } \\
\text { Usually } \\
\text { Always }\end{array}$ & $\begin{array}{c}116(28.5 \%) \\
225(55.3 \%) \\
53(13.0 \%) \\
13(3.2 \%)\end{array}$ \\
\hline $\begin{array}{l}\text { How do you remove a facemask? } \\
\text { (Please select your most common } \\
\text { method) }\end{array}$ & $\begin{array}{l}\text { Touching the front of } \\
\text { the mask to remove the } \\
\text { facemask } \\
\text { Hold both ear loops and lift } \\
\text { and remove the facemask }\end{array}$ & $\begin{array}{l}118(29 \%) \\
289(71 \%)\end{array}$ \\
\hline $\begin{array}{l}\text { Do you share a facemask with other } \\
\text { people }\end{array}$ & $\begin{array}{l}\text { Yes } \\
\text { No }\end{array}$ & $\begin{array}{c}33(8.1 \%) \\
374(91.9 \%)\end{array}$ \\
\hline $\begin{array}{c}\text { Do you keep a used facemask in your } \\
\text { pocket/ bag for later use? }\end{array}$ & $\begin{array}{l}\text { Yes } \\
\text { No }\end{array}$ & $\begin{array}{c}351(86.2 \%) \\
56(13.7 \%)\end{array}$ \\
\hline $\begin{array}{l}\text { How long do you use a single-use } \\
\text { facemask? }\end{array}$ & $\begin{array}{l}\text { Only once (for a single day) } \\
\text { For two times } \\
\text { Three times } \\
>3 \text { times }\end{array}$ & $\begin{array}{l}59(14.5 \%) \\
30(7.4 \%) \\
146(35.9 \%) \\
172(42.2 \%)\end{array}$ \\
\hline $\begin{array}{l}\text { How do you dispose a facemask you } \\
\text { used? }\end{array}$ & $\begin{array}{l}\text { Open disposal } \\
\text { In a pit/ bin } \\
\text { Burning } \\
\text { Toilet } \\
\text { In plastic bag }\end{array}$ & $\begin{array}{c}192(47.2 \%) \\
135(33.2 \%) \\
25(6.1 \%) \\
33(8.1 \%) \\
22(5.4 \%) \\
\end{array}$ \\
\hline Does the driver wear a facemask? & $\begin{array}{l}\text { Yes } \\
\text { No }\end{array}$ & $\begin{array}{c}20(4.9 \%) \\
387(95.0 \%)\end{array}$ \\
\hline $\begin{array}{l}\text { Does he/ she wear the facemask } \\
\text { correctly (not reverted, covered the nose, } \\
\text { mouth and chin fully }\end{array}$ & $\begin{array}{l}\text { Yes } \\
\text { No }\end{array}$ & $\begin{array}{c}17(4.2 \%) \\
390(95.8 \%)\end{array}$ \\
\hline
\end{tabular}

reported that they do not fear COVID-19, but the higher number of the respondents $215(52.8 \%)$ feel vulnerable to catching COVID-19, regarding obtaining facemask most of the respondents $344(84.5 \%)$ reported there is no difficulty in the availability of facemask and 215(52.8\%) of them believe that the purchase cost of face masks is not expensive, it is rather fair. Although most $300(73.7 \%)$ respondents feel discomfort when wearing a face mask while 219 (53.8\%) of the participants do not think the government pressurize them or felt enforced into wearing a face mask. More than half of them perceive neither family members $232(57 \%)$, nor passengers $356(87.5 \%)$ encourage them to wear a face mask. $235(57.7 \%)$ of the study participants do not think wearing face masks acceptable in their working area. In this study, the relationship between knowledge and behavior was not assessed whether good knowledge affects behavior or not (Table 5).

\section{Discussion}

Coronavirus disease 19 has been an ongoing global threat. Since the world is still under constant waves of uncertainties leaving drivers at even higher risks on daily basis than the general population. The risk of contracting the disease among drivers gives further enhances if it is accompanied by poor knowledge, attitude, and practices of personal protective equipment especially face masks. Hence, to mitigate the spread of this infection. This cross-sectional study was conducted with the aim of assessing the knowledge, attitude,

Table 5: Behavioral factors affecting facemask wearing of Public transport Drivers Debre-Tabor, Northern, Ethiopia, 2021.

\begin{tabular}{|c|c|c|}
\hline Variables & Categories & $n(\%)$ \\
\hline $\begin{array}{l}\text { Do you feel COVID-19 is a punishment from } \\
\text { GOD? }\end{array}$ & $\begin{array}{c}\text { Yes } \\
\text { No } \\
\text { Uncertain }\end{array}$ & $\begin{array}{c}303(74.4 \%) \\
53(13 \%) \\
51(12.5 \%)\end{array}$ \\
\hline $\begin{array}{l}\text { Do you feel COVID-19 is a bio-hazardous } \\
\text { attack manufactured in a lab.? }\end{array}$ & $\begin{array}{c}\text { Yes } \\
\text { No } \\
\text { uncertain }\end{array}$ & $\begin{array}{c}20(4.9 \%) \\
195(47.9 \%) \\
192(47.2 \%)\end{array}$ \\
\hline $\begin{array}{l}\text { Do you feel as you are vulnerable to catching } \\
\text { COVID-19? }\end{array}$ & $\begin{array}{c}\text { Yes } \\
\text { No } \\
\text { uncertain }\end{array}$ & $\begin{array}{c}215(52.8 \%) \\
159(39.1 \%) \\
33(8.1 \%)\end{array}$ \\
\hline Do you fear of COVID-19? & $\begin{array}{c}\text { Yes } \\
\text { No } \\
\text { uncertain }\end{array}$ & $\begin{array}{c}126(31 \%) \\
253(62.2 \%) \\
28(6.9 \%)\end{array}$ \\
\hline $\begin{array}{l}\text { Do you face difficulty in obtaining facemask? } \\
\text { (availability) }\end{array}$ & $\begin{array}{c}\text { Yes } \\
\text { No } \\
\text { uncertain }\end{array}$ & $\begin{array}{c}52(12.8 \%) \\
344(84.5 \%) \\
11(2.7 \%)\end{array}$ \\
\hline Do you feel that facemasks are expensive? & $\begin{array}{c}\text { Yes } \\
\text { No } \\
\text { uncertain }\end{array}$ & $\begin{array}{c}176(43.2 \%) \\
215(52.8 \%) \\
16(3.9 \%)\end{array}$ \\
\hline $\begin{array}{l}\text { Do you face discomfort when wearing a } \\
\text { facemask? }\end{array}$ & $\begin{array}{c}\text { Yes } \\
\text { No } \\
\text { uncertain }\end{array}$ & $\begin{array}{c}300(73.7 \%) \\
101(24.8 \%) \\
6(1.5 \%)\end{array}$ \\
\hline $\begin{array}{l}\text { Do you feel being pressurized by the } \\
\text { government to wear a facemask? }\end{array}$ & $\begin{array}{c}\text { Yes } \\
\text { No } \\
\text { uncertain }\end{array}$ & $\begin{array}{c}170(41.8 \%) \\
219(53.8 \%) \\
18(4.4 \%)\end{array}$ \\
\hline $\begin{array}{l}\text { Do your family members encourage you to wear } \\
\text { facemask? }\end{array}$ & $\begin{array}{c}\text { Yes } \\
\text { No } \\
\text { uncertain }\end{array}$ & $\begin{array}{c}158(38.8 \%) \\
232(57 \%) \\
4.2 \%)\end{array}$ \\
\hline $\begin{array}{l}\text { Do passengers encourage you to wear } \\
\text { facemask? }\end{array}$ & $\begin{array}{c}\text { Yes } \\
\text { No } \\
\text { uncertain }\end{array}$ & $\begin{array}{c}42(10.3 \%) \\
356(87.5 \%) \\
9(2.2 \%)\end{array}$ \\
\hline $\begin{array}{l}\text { Is wearing facemask acceptable in your working } \\
\text { area? }\end{array}$ & $\begin{array}{c}\text { Yes } \\
\text { No } \\
\text { uncertain }\end{array}$ & $\begin{array}{c}112(27.5 \%) \\
235(57.7 \%) \\
60(14.7 \%)\end{array}$ \\
\hline
\end{tabular}


and practice (KAP) Facemask Utilization and additional behavioral factors that affect facemask wearing among public transport drivers (taxi, bajaj, public service bus, Long run bus, and long-run minibus) in urban areas of Debre-Tabor town showed that majority of participant drivers were from the age range of 26-35 years of age with a mean age of 32.75 years. The majority of participants were males 383(94.1\%).

These findings are comparable with studies conducted in other parts of Africa. In a similar Nigerian study, the researchers reported mean age of HCWs(health care workers) was $32.3 \pm 9.9$ years [2]. However, other studies done to see KAP in general COVID-19 disease reported the highest proportion of HCWs being in these age groups with slightly higher mean age (34.9 \pm 9.3 years) and Male predominance $(50 \%)[6]$.

On the other hand, another Nigerian study reported the highest proportion in the age range of 31-40 years [7].

The current study revealed that the overall average knowledge, attitude and practice proportions of drivers gained from this were $90.4 \%, 40 \%$, and 5.6\% regarding facemask use against COVID-19 infection respectively, and the majority of study subjects $278(68 . \%)$ knew the transmission routes of COVID-19. But, on the other hand, almost half of respondents $216(53.0 \%)$ answered a face mask will not protect from COVID-19, 260(63.8\%) responded it is not necessary to wear a face mask even if you have been caught by COVID-19. Many of the $221(54.3 \%)$ do not know purpose of the metal strip on a surgical mask, and 229(56.3\%) were answer, are not aware of the characteristics/ differences between the different types of face masks (Surgical mask, N95, Cloth mask).

A study was done in Ghana an estimated 31.5\% (95\% CI: 27.8 - 35.1) of the students wore a face mask often or always [25]. A cross-sectional survey was conducted on all students studying in Vietnam at Phenikaa University, Hanoi, The most common types of masks used were surgical masks $57.6 \%$ followed by non-antibacterial cloth masks 23.1\%. Among 168 participants using non-antibacterial cloth masks, $43.5 \%$ reused masks (73/168), of whom $6.8 \%$ did not wash their masks at least daily [5].

A cross-sectional study was conducted among 417 taxi drivers in Gondar Town from July to August 2020. The proportion of taxi drivers who wore a facemask was $4.9 \%$ [95\% CI: 50.10 - 59.7\%] [5]. A study was conducted to assess mask utilization and physical distancing practices as a preventive response to covid-19 among them 53.2\% were female. Proper face mask utilization was practiced almost universally, 93.4\%. Proper physical distancing was practiced in $48.3 \%$ of them. the presence of individual enforcement, the daily patient load, and the capacity of the waiting areas were influencing the practice of proper physical distancing [9]. So, the prevalence of knowledge of mask utilization of the current study is more similar to the study conducted in Nigeria, the average knowledge, attitude and practice proportions of HCWs gained from this were $73.9 \%, 40.3 \%$, and $57.7 \%$ respectively. In Nigeria reported attitude toward PPE use was very low (14.5\%) urging nationwide practical training on PPE use [5]. Ugandan study demonstrated knowledge, attitude and practices being 69\%, 21\% and 74\% respectively [7]. Study from Gondar, Ethiopia was done to evaluate practice of preventive strategies against COVID-19. The result showed poor preventive practices among HCWs which was found to be around $38.7 \%$. Knowledge and attitude among HCWs were $64 \%$ and $70 \%$ respectively [8].

These differences might be as a result of different involvement of infection rates among Gondar and Addis Ababa where the number of daily infected people are higher putting HCWs at higher fear of contracting the disease hence higher complaint with applications of PPE (Personal Protective Equipment). It can be further strengthened by the fact that only $36 \%$ of HCW at Gondor reported consistent use of facemask at work pace whereas in the study 55\% of HCWs reported consistent use of face mask all the time [8]. The proportion of taxi drivers who wore a facemask was $54.68 \%$ [95\% CI: 50.10 - 59.7\%] in the Dessie and Kombolcha Town. The majority (58.3\%) of drivers were using cloth facemasks, followed by N95 facemasks (24.5\%) and surgical facemasks $(17.3 \%)$ while in this current study the commonly used type of mask is surgical Facemask. Out of the total 417 taxi drivers, more than two-thirds (69.8\%) of them had good knowledge about COVID-19 and $67.6 \%$ of taxi drivers had a positive attitude towards taking precautions against the transmission of COVID-19. Three-fourths (74.1\%) of the taxi drivers believed that wearing a facemask could prevent COVID-19. More than half $(52.5 \%)$ felt discomfort when wearing a facemask. Almost three-fourths (72.2\%) of taxi drivers felt that the presence of local government pressure helped them to wear a facemask.

When we compared to the study conducted from kombucha taxi drivers, our study respondents were a high score of knowledge, but it have less score on attitude and practice of face mask utilization.

Generally, the study conducted from drivers and research conducted from health care workers has a dominantly difference of face mask utilization on its knowledge, attitude, and practice using a face mask to prevent the transmit ion of COVID-19 pandemic conducted among drivers Gondar town, Ethiopia.

\section{Conclusion}

The current study was able to demonstrate $90.4 \%$ of drivers had good knowledge. Positive attitude and practice levels of face mask use among drivers were less than half of them or $40 \%$, and $5.6 \%$ respectively. There is a high supply of surgical face masks but poor attitude and practice. Almost all of the participants don't wear a face mask despite having good knowledge about transmission routes of COVID-19. 
The government, COVID-19 prevention task force or health sector should be continued their awareness creation to bring behavioral change for the implementation of the COVID-19 prevention method, especially facemask.

\section{Limitations of the study}

One of the limitations of this study was its study area since it was only limited to Debre-Tabor town public transport drivers and it was difficult to generalize to other area drivers. The other limitation is its study design which the study was cross-sectional that captures data points at a given time and therefore might not be accurate as time progresses, and this study did not have sufficient literature which was conducted in the five types of vehicles (Bajaj, Taxi, Public service, Longrun Minibus, and Bus) discussion was made based on findings from different Source populations and studies conducted in other areas.

\section{Declarations}

Ethical approval and consent to participate: Ethical clearance was obtained from Debre-Tabor University research ethics review board, school of medicine with Ref no, IRB/schemed/0251/2021. Then, a support letter with this was offered to Debre-Tabor town administration Health Bureau, and we got permission from each Keble's administrative. Participation of all respondents was ensured informed written consent before engaging in the study. We acquired measures to assure the respect, norms, values, beliefs, culture, and freedom of each individual participating in the study. Information on the purpose and procedures of the study were explained; confidentiality was maintained by omitting their identifications such as names and assured a great deal of care and the information obtained is anonymized to all study participants.

Availability of the data: Data will be available upon request from the corresponding author.

\section{Acknowledgment}

The authors are very grateful to the Debre-Tabor University, college of medicine and health science for providing the opportunity to do this. Would like to acknowledge data collectors and supervisors for their skilled work and support. Finally, we would like to offer our gratitude to the participants for their full and honest cooperation.

Authors' contribution: All authors made substantial contributions to the conception, design, acquisition of data, or analysis and interpretation of data. And took part in drafting the article or revising it critically for important intellectual content; agreed to submit to the current journal; gave final approval of the version to be published, and agree to be accountable for all aspects of the work. All authors have read and approved the final manuscript.

\section{References}

1. Kadeh H, Saravani S, Golzari P. Knowledge, attitude and practice of dentists towards patients with HIV, Hepatitis B and Hepatitis C infections. 2014

2. Agarwal S, Punn NS, Sonbhadra SK, Tanveer M, Nagabhushan $P$, et al Unleashing the power of disruptive and emerging technologies amid COVID-19: A detailed review. arXiv preprint arXiv: 2020; 200511507.

3. Banik R, Rahman M, Sikder MT, Rahman QM, Pranta MUR. Knowledge, attitudes, and practices related to the COVID-19 pandemic among Bangladeshi youth: a web-based cross-sectional analysis. J Public Health. 2021: 1-11.

PubMed: https://pubmed.ncbi.nlm.nih.gov/33680713/

4. Ciotti M, Ciccozzi M, Terrinoni A, Jiang WC, Wang CB, et al. The COVID-19 pandemic. Cri Rev Clin Laboratory Sci. 2020; 57: 365-388. PubMed: https://pubmed.ncbi.nlm.nih.gov/32645276/

5. Duong MC, Nguyen HT, Duong BT. A Cross-Sectional Study of Knowledge, Attitude, and Practice Towards Face Mask Use Amid the COVID-19 Pandemic Amongst University Students in Vietnam. J Community Health. 2021: 975-981.

PubMed: https://pubmed.ncbi.nlm.nih.gov/33772684/

6. Eibensteiner F, Ritschl V, Stamm T, Cetin A, Schmitt CP, et al Countermeasures against COVID-19: how to navigate medical practice through a nascent, evolving evidence base-a European multicentre mixed methods study. BMJ Open. 2021; 11: e043015. PubMed: https://pubmed.ncbi.nlm.nih.gov/33597140/

7. Islam SDU, Mondal PK, Ojong N, Bodrud-Doza M, Siddique MAB, et al. Water, sanitation, hygiene and waste disposal practices as COVID-19 response strategy: insights from Bangladesh. Environ Develop Sustainabil. 2021: 1-22.

PubMed: https://pubmed.ncbi.nlm.nih.gov/33424423/

8. Bakkar B, Mohsen F, Armashi H, Marrawi M, Aldaher N. A Crisis within a Crisis: An Assessment of COVID-19 Attitude and Practice among Syrians-A Cross-sectional Study. 2021.

9. Akalu Y, Ayelign B, Molla MD. Knowledge, attitude and practice towards COVID-19 among chronic disease patients at Addis Zemen Hospital, Northwest Ethiopia. Infection Drug Resistance. 2020; 13: 1949-1960. PubMed: https://pubmed.ncbi.nlm.nih.gov/32612371/

10. Klucarova S. Do masks matter? Consumer perceptions of social media influencers who wear face masks amid the COVID-19 pandemic. Appl Psychol. 2021.

11. Alahdal $H$, Basingab $F$, Alotaibi R. An analytical study on the awareness, attitude and practice during the COVID-19 pandemic in Riyadh, Saudi Arabia. J Infect Public Health. 2020; 13: 1446-1452. PubMed: https://pubmed.ncbi.nlm.nih.gov/32563674/

12. Peng Y, Pei C, Zheng Y, Wang J, Zhang K, et al. A cross-sectional survey of knowledge, attitude and practice associated with COVID-19 among undergraduate students in China. BMC Public Health. 2020; 20: 1-8.

PubMed: https://pubmed.ncbi.nlm.nih.gov/32847554/

13. Chu DK, Akl EA, Duda S, Solo K, Yaacoub S, et al. Physical distancing, face masks, and eye protection to prevent person-to-person transmission of SARS-CoV-2 and COVID-19: a systematic review and meta-analysis. Lancet. 2020; 395: 1973-1987.

PubMed: https://pubmed.ncbi.nlm.nih.gov/32497510/

14. Van der Sande M, Teunis $P$, Sabel R. Professional and home-made face masks reduce exposure to respiratory infections among the general population. PloS One. 2008; 3: e2618.

PubMed: https://pubmed.ncbi.nlm.nih.gov/18612429/

15. Maclntyre CR, Chughtai AA. Facemasks for the prevention of infection in healthcare and community settings. BMJ. 2015; 350.

PubMed: https://pubmed.ncbi.nlm.nih.gov/25858901/

16. Tian L, Li X, Qi F, Tang QY, Tang V, et al. Harnessing peak transmission 
around symptom onset for non-pharmaceutical intervention and containment of the COVID-19 pandemic. Nat Commun. 2021; 12: 1147. PubMed: https://pubmed.ncbi.nlm.nih.gov/33608519/

17. Mitchell T, Dee DL, Phares CR, Lipman HB, Gould LH, et al. Nonpharmaceutical interventions during an outbreak of 2009 pandemic influenza A (H1N1) virus infection at a large public university, AprilMay 2009. Clin Infect Dis. 2011; 52(suppl_1): S138-S45.

PubMed: https://pubmed.ncbi.nlm.nih.gov/21342886/

18. Aledort JE, Lurie N, Wasserman J, Bozzette SA. Non-pharmaceutical public health interventions for pandemic influenza: an evaluation of the evidence base. BMC Public Health. 2007; 7: 208.

PubMed: https://pubmed.ncbi.nlm.nih.gov/17697389/

19. Schwartz IB, Kaufman JH, Hu K, Bianco S. Predicting the impact of asymptomatic transmission, non-pharmaceutical intervention and testing on the spread of COVID-19. medRxiv. 2020.

20. Sharma SK, Mishra M, Mudgal SK. Efficacy of cloth face mask in prevention of novel coronavirus infection transmission: A systematic review and meta-analysis. J Educat Health Promotion. 2020; 9; 192. PubMed: https://pubmed.ncbi.nlm.nih.gov/33015206/

21. Tso RV, Cowling BJ. Importance of Face Masks for COVID-19: A cal for effective public education. Clin Infect Dis. 2020; 71: 2195-2198. PubMed: https://pubmed.ncbi.nlm.nih.gov/32614045/

22. Barenghi L, Barenghi A, Gianni A, Spadari F. Problems on going during the application of guidelines for COVID-19 prevention in dentistry. 2020.

23. Lyu W, Wehby GL. Community Use of Face Masks and COVID-19: Evidence from a Natural Experiment of State Mandates in the US: Study examines impact on COVID-19 growth rates associated with state government mandates requiring face mask use in public. Health Aff. 2020; 39: 1419-1425.

PubMed: https://pubmed.ncbi.nlm.nih.gov/32543923/

24. Ibn-Mohammed T, Mustapha K, Godsell J, Adamu Z, Babatunde K, et al. A critical review of the impacts of COVID-19 on the global economy and ecosystems and opportunities for circular economy strategies. Resour Conserv Recycl. 2020; 105169.

PubMed: https://pubmed.ncbi.nlm.nih.gov/32982059/

25. Nkansah C, Serwaa D, Adarkwah LA, Osei-Boakye F, Mensah K, et al. Novel coronavirus disease 2019: knowledge, practice and preparedness: a survey of healthcare workers in the Offinso-North District, Ghana. Pan African Med J. 2020; 79.

PubMed: https://www.ncbi.nlm.nih.gov/pmc/articles/PMC7875802/ 